\title{
High polar spatial competition: extreme hierarchies at extreme latitude
}

\author{
David K. A. Barnes ${ }^{1, *}$, Piotr Kukliński ${ }^{2,3}$ \\ ${ }^{1}$ British Antarctic Survey, High Cross, Madingley Road, Cambridge CB3 0ET, UK \\ ${ }^{2}$ University Courses on Svalbard (UNIS), PO Box 156, Longyearbyen 9171, Norway \\ ${ }^{3}$ Institute of Oceanology, Polish Academy of Sciences, Marine Ecology Department, ul. Powstańców Warszawy 55, \\ Sopot 81-712, Poland
}

\begin{abstract}
On polar shores, as at lower latitude, intense battles for space ensue on boulders but the high wind, wave and ice disturbance make the colonisation race a short one in time. Here we test multiple hypotheses on the nature of competition at a high polar latitude $\left(77^{\circ} \mathrm{N}\right.$, Arctic Spitsbergen): that interference competitive encounters would principally be (1) between colonial animals and (2) intraspecific in nature involving very few species; (3) intraspecific interactions would mostly result in ties and (4) interspecific interactions would conversely result in overgrowth, involve mainly 1 poor competitor species interacting with many others; and that (5) competition structure would be highly hierarchical. This is the highest latitude of any competition study and its structure was as extreme as hypothesised in many respects. Interference competition on boulders was dominated by encounters between colonial animals (almost entirely between cheilostome bryozoans). Nearly $80 \%$ of all competitor interactions were intraspecific. Most intraspecific encounters involved just a single (bryozoan) species, Harmeria scutulata. In no other equivalent assemblage is there such an extreme balance of intra- to interspecific competition. Nearly $97 \%$ of intraspecific fights for space ended in tied outcomes (standoffs). We can also find no described assemblage in which tied outcomes are so frequent in intraspecific encounters or so rare in interspecific meetings. Of the competitors present in more than 10 interactions $H$. scutulata was the poorest, winning just $24 \%$ of encounters with other species. No other study, known to us, has shown an assemblage to be so dominated by a single species, which is such a poor spatial competitor. Compared to other similar assemblages the diversity (ShannonWiener $H^{\prime}$ ) and evenness (Pielou's $J$ ) of competitive encounters was lowest. This Spitsbergen assemblage is also the most severe hierarchy measured in a marine encrusting community. These findings have major implications for the response of the community to disturbance and climate change.
\end{abstract}

KEY WORDS: Community structure $\cdot$ Transitivity $\cdot$ Species monopolies $\cdot$ Polar biodiversity

\section{INTRODUCTION}

Darwin (1859) and ecologists since have considered competition for resources critical to the success of individuals and ultimately to the structure of organism communities. Interference or contest competition involves physical or chemical contact between rivals. It is a rare and valuable tool for ecologists, as it is one of the few interactions between organisms which may be easily observed and measured across a wide range of organisms. In certain taxa, the interactions may, in addition, be well preserved in the fossil record. Interference competition between 2 competitors has 3 possible outcomes for a potential competitor, a win (it overgrows its rival), a loss (it is overgrown by its rival) and a tie (no net loss or gain). Whereas tied results (standoffs, mutual overgrowth or even fusion) are not uncommon in sessile or colonial animals (Schmidt \& Warner 1986, Tanaka \& Nandakumar 1994), such an outcome is rare in meetings between mobile forms (Wagnon et al. 1966, Clutton-Brock et al. 1979). For a long time organism battles were thought to be 
restricted to between 'like' competitors but it has become clear that very distantly related and morphologically dissimilar species may also frequently be direct competitors (Diamond 1987, Hochberg \& Lawton 1990). Much of the literature on interference competition between organisms tends to be restricted to a particular group or clade. There can be major interpretive advantages in taxonomically restricting study to representatives of just 1 clade (Jackson 1979). These include minimising confounding factors, so wide scale trends in competition structure can be investigated (Barnes 2002).

Most studies of competition undertaken are carried out on a small-scale and use single points in time or 'snapshots'. To interpret the context and underlying meaning of such snapshots, studies which compare competition in space and time at a variety of spatial scales are needed. Powerful analyses require many observations of interactions. Environments such as shores are ideal study sites as intense competition can be easily observed. The intense fight for space on rocky and boulder littoral and sublittoral zones involves many sessile organisms, whose interactions can be observed in detail, in large numbers and even followed over time. Thus interactions between lithophyllic encrusting taxa have proved a vital key to understanding the outcomes, causes and effects of competition (Connell 1961, Dayton 1971, Paine 1974, Jackson 1979, Sebens 1986, Tanaka \& Nandakumar 1994, McKinney 1995). In the bryozoans, a common colonial lithophyllic taxon, interference competition is hierarchical at high latitude and more intransitive in the tropics (Barnes 2002); towards the poles the 'pecking order' is more severe. Communities therefore have an increasingly more dominant competitor, ranging through species with a spectrum of competitive ability to one increasingly more submissive to all others. At equatorial latitudes the structure of competitive interactions in bryozoans, corals and other encrusting marine benthos more closely resembles a network with no clear ranking of competitors (Buss \& Jackson 1975, Tanner 1997). A number of interspecific competition features can contribute to the prevalence of networks, for example: incomplete dominance of superior competitors leading to the formation of what are termed backloops (in which an inferior competitor may beat a higher ranked competitor). High frequencies of tied outcomes (Quinn 1982, Russ 1982, Schmidt \& Warner 1986, Sebens 1986, Chornesky 1989, Tanaka \& Nandakumar 1994) or more complex non-contact interactions (Schoener 1983, Menge \& Sutherland 1987) can also promote network structures. In some clonal taxa, intraspecific meetings can regularly be cooperative rather than competitive (Karlson 1999). This is important, as it makes the implications of intraspecific and interspecific competition quite different. Fusion of colonies or homosyndrome on meetings between 2 conspecific bryozoans is a good example of this (Knight-Jones \& Moyse 1963, Craig 1994, Barnes \& Clarke 1998). Such authors and others have noted it only rarely in this taxon (our main study group) and Barnes \& DeGrave (2002) found both intraspecific and interspecific crowding to have similar effects on growth and perseverence of colonies. Although hierarchical community structures have been established in southern Alaska and the Antarctic Peninsula region (Barnes 2002), competition is yet to be investigated in any high polar region. Understanding community and competition structure at high latitudes is important as nowhere has global climate and environmental change been predicted (Murphy \& Mitchell 1995) or reported to be as fast (Farman et al. 1985, Denisenko \& Denisenko 1995, Quale et al. 2002, Walther et al. 2002). Highly hierarchical polar communities, unlike tropical networks with biologically mediated diversity, require environmental disturbance to prevent ultimately competitive dominant species from monopolising space. To interpret ecological response to climate change we need to understand the patterns and causes of high latitude community structure.

Here we investigate interference competition amongst the shallow marine lithophyllic assemblages on the west coast of Spitsbergen, Svalbard $\left(77^{\circ} \mathrm{N}\right)$. As the assemblage to be studied was on subtidal boulders at high latitude we hypothesised that (1) interference competition would be dominated by encounters between colonial animals, more specifically bryozoans; (2) the nature of these interference competitive encounters would largely be intraspecific interactions involving few, possibly just 1 species; (3) intraspecific interactions would mainly result in tied outcomes (standoffs); (4) interspecific interactions would mainly result in overgrowth (rather than ties/standoffs), involving principally just 1 species interacting with many others and this species would be a poor competitor; and (5) assemblage competition structure would be highly hierarchical. Finally, possible implications for community structure stability and nearshore marine biodiversity are discussed in the context of polar warming.

\section{MATERIALS AND METHODS}

Study area and species. The study area was Hornsund Fjord, West Spitsbergen, in the high arctic $\left(77^{\circ} \mathrm{N}\right.$, $\left.15^{\circ} \mathrm{E}\right)$. The sea temperature at the time of material collection, in July 2002 , was $3^{\circ} \mathrm{C}$, but varies annually from approximately -1.8 to $4^{\circ} \mathrm{C}$. The inner fjord is characterised by winter (mid-December to end of May) cover- 
age of fast-ice (frozen sea surface) and is subject to ice scour from floating ice during the summer months. The central and outer parts of the fjord are only occasionally covered with fast ice (Wẹsławski et al. 1988). The salinity regime of near bottom waters varies from 33 to $34 \mathrm{psu}$. The surface salinity dropped rapidly during snow melting in June from about 32 to 25 psu and less (Swerpel 1985, Węsławski et al. 1988). Details of the oceanography and seasonality of the Horsund Fjord ecosystem are described by Swerpel (1985) and Wẹsławski et al. (1988) and the distribution and biomass in the intertidal and coastal boulders have been examined by Wẹsławski et al. (1993).

The suite of lithophyllic potential competitors for space was mainly cheilostomatid bryozoans, but also included cyclostomatid bryozoans, balanomorph barnacles, colonial ascidians, tubicolous polychaetes and occasional calcarea and demosponge Porifera. The studied species were Tegella arctica d'Orbigny, T. armifera Hincks, Cribrilina annulata Fabricius, Cauloramphus intermedius Kluge and Harmeria scutulata Busk. These are well known and common boreal-arctic cheilostomes. One competitor, Pentapora sp. nov., is in the process of being described for the first time.

Protocol. The surface area of 54 randomly selected boulders, from the shallow sublittoral (6 m depth) of Hornsund Fjord, West Spitsbergen, was estimated using an inelastic net marked in a grid of $\mathrm{cm}^{2}$. The number and identity of all colonists and the interactions (aggressive encounters) between them were recorded. Contact between 2 or more colonists was designated as an interaction if both were live and $5 \%$ or more of the organism periphery was affected. Interactions were, in conjunction with the established literature (Sebens 1986, Tanaka \& Nandakumar 1994, Barnes 2002), scored as overgrowth (i.e. a win for one of the competitors) if the loser's feeding apparatus was obscured. A tied outcome was scored when mutual, but equal, overgrowth took place or skeletal build-up, but without any overgrowth (sometimes termed a standoff), occurred. Tied outcomes are often temporally stable and not simply a delay to an eventual win or loss (Sebens 1986, Tanaka \& Nandakumar 1994, authors' pers. obs.). Nevertheless, losers can sometimes survive, if the overgrower subsequently recedes, such as bryozoans recovering from ascidian temporary smothering (Todd \& Turner 1988). As most of the interactions in the present study only involved cheilostomatid bryozoans this is unlikely to be an important consideration. Data were arranged into species-pair contact-matrices, but only competitor species involved in at least 10 interactions were included. A number of features of the data were calculated: (1) the proportion of interspecific (relative to intraspecific) interactions, (2) the proportion of interspecific interactions resulting in tied outcomes, (3) the proportion of the total number of competitive encounters which involved the most abundant species, and (4) the competitive rank of the most abundant species. Competitive rank was determined using the proportion of wins to total interactions. The proportion of losses to total interactions was also calculated and tabulated for each species as some species may be involved in many tied interactions. A different answer is then obtained to the reciprocal of its win/total score.

The underlying structure of the interference competitive outcomes was investigated by gauging the extent to which competition was hierarchical (transitive). For example if A mostly overgrew B and C, and B mostly overgrew $\mathrm{C}$ this would be highly transitive and so give a high value on a hierarchical index. We used Tanaka \& Nandakumar's (1994) transitivity index because it is accurate and useful for wider comparison. It is particularly valuable due to its independence from competitor or observation number. Tanaka \& Nandakumar (1994) formulated 3 indices but we used just the win index, WI:

$$
\mathrm{WI}=\sqrt{\frac{\sum_{i=1}^{n} \sum_{j=1}^{n} P_{i j}[\mathrm{~W}]^{2}}{\frac{n(n-1)}{2}}}
$$

where $P_{i j}[\mathrm{~W}]$ is the probability for a win of species $i$ over species $j$ and $n$ is the total number of species considered.

Comparison with data from the literature. Data here were compared with Barnes (2002) as this, like the current data, involved similar definitions and taxa in competition. The number of species which met in competition was calculated as a proportion of the total possible, for a matrix of 6 and then (separately) 7 competitors. For example a matrix of 6 species has $6+5+$ $4+3+2+1=21$ possible competitor pairings. In each case, the species selected for the comparison between studies were those which met most other competitors. These sizes of contact matrices were the maximum usable to allow comparison of all relevant data in the literature. The number of meetings for each competitor pairing was listed for each assemblage for measurements of competition diversity with locality (ShannonWiener $H^{\prime}$ and Pielou's $J$ ). The features of each data that were calculated were the same as those for the current data set.

Data analysis included a number of standard techniques. We used $\chi^{2}$ tests to analyse whether certain competitors were significantly better than others in particular pairings. We plotted the mean probability of competition and colonisation against $\log _{10}$ transformed rock area. Lines of best fit were tested for, which 


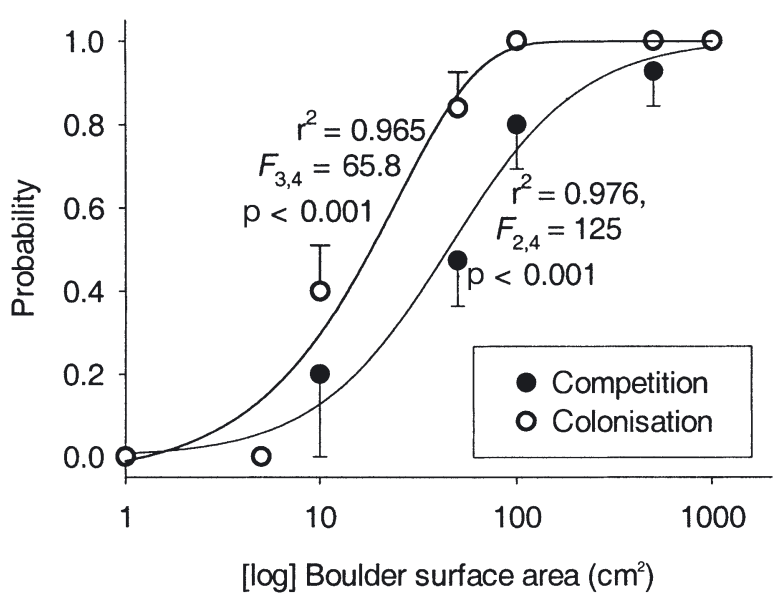

Fig. 1. Occurrence of fauna and faunistic spatial competition with surface area of high arctic boulders. Both fitted sigmoidal curves are logistic regressions for which the degree of fit and significance (ANOVA) are indicated on the plot. Data are shown as mean \pm SE $(n \geq 4)$ for size classed boulders. No boulders of certain size classes (e.g. $1 \mathrm{~cm}^{2}$ ) and all boulders of others (e.g. $100 \mathrm{~cm}^{2}$ ) were colonised, so no standard error was associated with these points. Symbols are presence of fauna (O) and measurable interference competition

included logistic and standard linear regression. In each case ANOVA was performed on the relationships and fits $\left(\mathrm{r}^{2}\right)$, test statistic $(F)$ and significance $(\mathrm{p})$ values when significant. This was repeated for various features of competition, plotted against locality latitude.

\section{RESULTS}

\section{Competitor and competition prevalence}

Faunal presence on the boulders sampled exhibited a good fit to a logistic relationship with substratum surface area (Fig. 1). Based on this model, the probability of lithophyllic faunal presence on boulders of surface area $<5 \mathrm{~cm}^{2}$ was near zero and near unity at $>100$ $\mathrm{cm}^{2}$, i.e. nearly all boulders $>100 \mathrm{~cm}^{2}$ had some colonisation. Biota mainly colonised a small proportion of (under-surface) space on the high arctic boulders. So although overall space was not limiting, within restricted areas of each boulder competition for space was intense. Recruitment of fauna was almost entirely confined to the under-surfaces of boulders. The incidence of spatial competition on boulders also showed a good fit to a logistic model (Fig. 1). Interpretation of this model suggested only boulders $<8 \mathrm{~cm}^{2}$ surface area were likely to have no faunistic competition but that virtually all boulders $>500 \mathrm{~cm}^{2}$ in surface area would show evidence of competitive interactions between colonists. So the bigger the boulder was, the higher the recruitment possible and, therefore, the more interactions possible. Although various ascidians, balanomorph barnacles, sponges, tubicolous polychaetes and cyclostome bryozoans were also present, cheilostome bryozoans dominated the number of colonists and competitive encounters (Table 1). Furthermore just 1 species of cheilostomatid, Harmeria scutulata, accounted for more than $75 \%$ of all colonists and was involved in most of the competitive interactions measured. H. scutulata was, however, one of the poorest spatial competitors. This species won only $24 \%$ of its interspecific interactions (Table 1) and most of those fights for space not won were lost (rather than tied). H. scutulata was the poorest bryozoan competitor with sheet-like growth form; only the chain-like bryozoan Electra arctica and the unitary barnacle Semibalanus balanoides were poorer at maintaining space.

Interspecific competition showed a simple log-linear increase with boulder surface area whilst the increase in intraspecific competition with substratum size was less predictable (Fig. 2). Most inter- and intraspecific

Table 1. Various cheilostomatid bryozoans and the barnacle Semibalanus balanoides. Rows are identities of all species for which interference competition was observed. Columns are density, total number of competitor species encountered, total number of interspecific encounters, number of wins divided by total number of encounters (W/T) and number of losses divided by total number of encounters $(\mathrm{L} / \mathrm{T})$

\begin{tabular}{|c|c|c|c|c|c|}
\hline Species & Mean no. recruits $\mathrm{m}^{-2}$ & $\begin{array}{l}\text { No. competitors } \\
\text { encountered }\end{array}$ & $\begin{array}{l}\text { No. interspecific } \\
\text { interactions }\end{array}$ & $\mathrm{W} / \mathrm{T}$ & $\mathrm{L} / \mathrm{T}$ \\
\hline Tegella retroversa & 46.17 & 3 & 35 & 0.914 & 0.09 \\
\hline Tegella arctica & 83.95 & 4 & 35 & 0.77 & 0.23 \\
\hline Cribrilina annulata & 156.77 & 3 & 10 & 0.7 & 0.30 \\
\hline Tegella armifera & 85.21 & 3 & 16 & 0.625 & 0.187 \\
\hline Cauloramphus intermedius & 67.20 & 4 & 39 & 0.51 & 0.462 \\
\hline Stomachatosella cruenta & 53.95 & 2 & 3 & 0.333 & 0.667 \\
\hline Harmeria scutulata & 3091.30 & 7 & 114 & 0.24 & 0.728 \\
\hline Electra arctica & 27.75 & 1 & 1 & 0.0 & 1.0 \\
\hline Semibalanus balanoides & 278.41 & 1 & 2 & 0.0 & \\
\hline
\end{tabular}


encounters involved colonies of Harmeria scutulata (Table 2). By far the single most common pair-wise interaction was $H$. scutulata colonies meeting other $H$. scutulata colonies, which usually ended in a tied outcome. In striking contrast, in only a single interspecific competitive encounter was a tied result recorded. All species, which were involved in at least 10 competitive encounters (shown in the competition matrix of Table 2), won the significant majority of those against $H$. scutulata ( $\chi^{2}$ test, $\mathrm{p}<0.05$ in all cases).

Reference to, and use of data from, the literature suggests aspects of spatial competition within the Spitsbergen shallow benthic assemblage in the current study were highly unusual and extreme, even by comparison with fights for space on boulders at $68^{\circ} \mathrm{S}$ - the previously highest latitude equivalent data (Table 2, adapted from Barnes \& Clarke 1998; data from Barnes 2000, Barnes 2002 and references therein). Of the different permutations of competitor meetings possible in a 6 species matrix, less than $60 \%$ occurred in our Spitsbergen data and even fewer if a 7 species matrix is considered (Fig. 3a,b). In both cases this is the lowest proportion of these types of interaction from any location worldwide. This contributes to the low diversity
(Shannon $H^{\prime}$ ) and evenness (Pielou's $J$ ) values of competitive pairings of the Spitsbergen assemblage (Fig. 4). Whilst these values are the lowest reported,

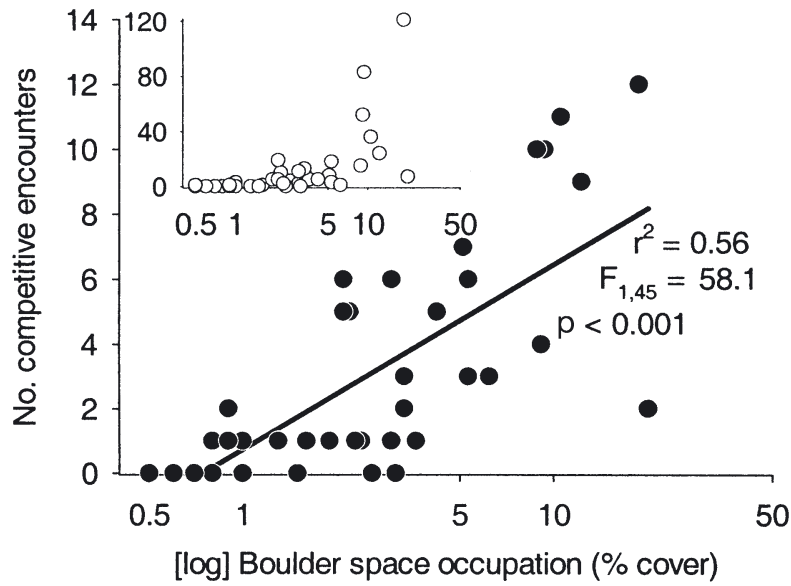

Fig. 2. Abundance of competitive encounters between fauna with space occupation on high arctic boulders. Fitted line is regression for which the degree of fit and significance (ANOVA) are indicated on the plot. Symbols are intraspecific $(\bigcirc$, insert) and interspecific competition $(\bullet$, main plot $)$

Table 2. Matrix of competitive interactions for Arctic (Spitsbergen Island) and Antarctic (Adelaide Island) cheilostomatid bryozoans. Data for Antarctic matrix from Barnes \& Clarke (1998) are displayed in standard form: see Turner \& Todd (1994), Barnes (2002). If rows $=$ Competitor $A$ and columns $=$ Competitor $B$, for each cell the top left, top right and bottom left data give, respectively, the number of ties between Species A and B, wins by B (= losses by A) and wins by A (= losses by B). Number in the bottom right of each cell is the total number of observed interactions for that species pair

\begin{tabular}{|c|c|c|c|c|c|c|c|c|c|}
\hline \multirow{2}{*}{$\frac{\text { Arctic } 77^{\circ} \mathrm{N}}{\text { Tegella retroversa }}$} & T. retroversa & T. arctica & T. armifera & \multicolumn{2}{|c|}{ C. annulata } & \multicolumn{2}{|c|}{ C. intermedius } & \multicolumn{2}{|c|}{ H. scutulata } \\
\hline & 0 & 0 & 0 & 0 & 0 & 0 & 0 & 0 & 3 \\
\hline & 0 & 0 & 0 & 0 & 0 & 5 & 5 & 26 & 29 \\
\hline \multirow[t]{2}{*}{ Tegella arctica } & & 0 & 0 & 0 & 1 & 0 & 0 & 0 & 7 \\
\hline & & 0 & 0 & 2 & 3 & 1 & 1 & 23 & 30 \\
\hline \multirow[t]{2}{*}{ Tegella armifera } & & & 1 & 0 & 0 & 0 & 0 & 3 & 3 \\
\hline & & & 1 & 1 & 1 & 1 & 1 & 8 & 14 \\
\hline \multirow[t]{2}{*}{ Cribrilina annulata } & & & & 0 & & 0 & 0 & 0 & 0 \\
\hline & & & & 0 & 0 & 0 & 0 & 6 & 6 \\
\hline \multirow[t]{2}{*}{ Cauloramphus intermedius } & & & & & & 0 & & 1 & 11 \\
\hline & & & & & & 0 & 0 & 20 & 32 \\
\hline Harmeria scutulata & & & & & & & & $\begin{array}{r}450 \\
25\end{array}$ & 475 \\
\hline Antarctic $68^{\circ} \mathrm{S}$ & A. inchoata & $X$. rangifer & Smittina sp. & \multicolumn{2}{|c|}{ F. rugula } & \multicolumn{2}{|c|}{ C. antarctica } & \multicolumn{2}{|c|}{ A. antarctica } \\
\hline \multirow[t]{2}{*}{ Arachnopusia inchoata } & 0 & 0 & 0 & 0 & 0 & 0 & 0 & 0 & 0 \\
\hline & 0 & 2 & 3 & 18 & 18 & 3 & 3 & 6 & 6 \\
\hline \multirow[t]{2}{*}{ Xylochotridens rangifer } & & 1 & 0 & 1 & 1 & 0 & 0 & 0 & 0 \\
\hline & & 0 & 0 & 15 & 17 & 0 & 0 & 5 & 5 \\
\hline \multirow[t]{2}{*}{ Smittina sp. } & & & 1 & 0 & 2 & 0 & 0 & 0 & 0 \\
\hline & & & 0 & 9 & 11 & 0 & 0 & 0 & 0 \\
\hline \multirow[t]{2}{*}{ Fenestrulina rugula } & & & & 338 & & 0 & 1 & 1 & 3 \\
\hline & & & & 2 & 340 & 4 & 5 & 7 & 11 \\
\hline \multirow[t]{2}{*}{ Celleporella antarctica } & & & & & & 0 & & 0 & 1 \\
\hline & & & & & & 0 & 0 & 1 & 2 \\
\hline \multirow[t]{2}{*}{ Aimulosia antarctica } & & & & & & & & 0 & \\
\hline & & & & & & & & 0 & 0 \\
\hline
\end{tabular}




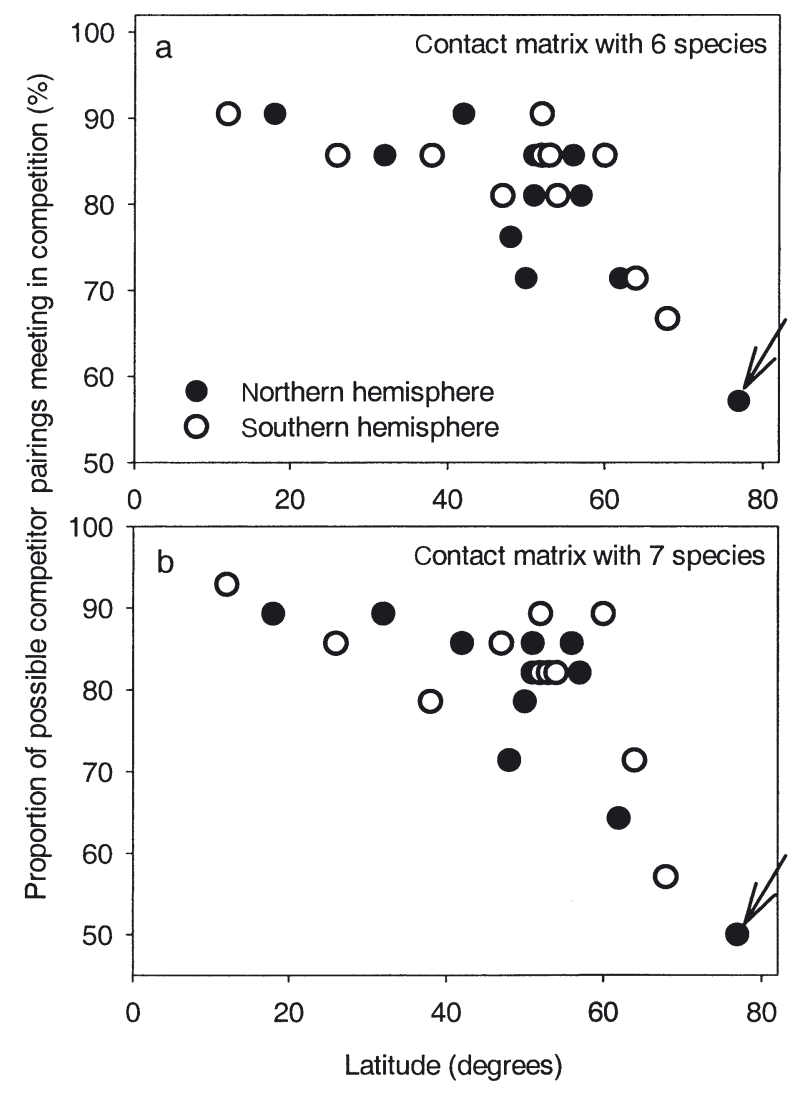

Fig. 3. Proportion of possible competitor pairings actually meeting in assemblages with latitude. The data are shown for (a) a 6 and (b) a 7 species matrix, by southern (O) and northern (๑) hemisphere (present study indicated by arrow)

they are similar to those from the next highest latitude study (Barnes \& Clarke 1998).

Just $20 \%$ of interactions in this study were interspecific. This was, to our knowledge, the lowest so far reported. Literature data and ours showed tropical competition to be dominated (60 to $90 \%$ ) by interspecific encounters between lithophyllic encrusting biota. In contrast, intraspecific interactions were more common in polar assemblages though any trend is probably non-linear (Fig. 5a). A similar pattern was apparent in the proportion of decided versus undecided outcomes (win or loss vs ties) with latitude. Whilst interspecific ties were common $(>15 \%)$ in tropical and subtropical assemblages they were rare in polar assemblages (Fig. 5b). Only $3.1 \%$ of interspecific interactions in our Spitsbergen data ended in tied outcomes. Intraspecific competitive encounters, however, nearly always $(94.5 \%)$ ended in tied outcomes (Table 2) similarly to high Antarctic data. Interspecific competition in our high arctic assemblage was also characterised by extreme levels of transitivity (Fig. 5c). Very high transitivity, such as was found here, means that competitors are organised into a strict hierarchy, in which 1 species is almost completely dominant. Furthermore, at the bottom of a pecking order is a species which is beaten by all competitors. At our high arctic site it was Harmeria scutulata, the most abundant species. Although higher than any other previously reported using Tanaka \& Nandakumar's (1994) index, the value did nevertheless lie close to that predicted for this latitude by Barnes (2002).

The competitive rank of the most abundant species at each locality decreased with latitude, with a value of only one-sixth (0.167) at West Spitsbergen (Fig. 6). The most abundant species in tropical and subtropical assemblages were typically high ranked spatial competitors. At temperate latitudes the most abundant species varied widely in terms of competitive performance whereas highly numerous polar species were all low ranked. The variability of this measure in temperate zones was a major factor in the fitted relationship (regression). Latitude explained just $49 \%$ of the variability.

\section{DISCUSSION}

Anyone who glances at coastal boulders along polar coastlines (above or below the littoral zone) can see that organisms occupy little space on them. In addition to plenty of space, polar benthos has typically low colonisation and growth (Arntz et al. 1994, Barnes 2000). Therefore, the suggestion that competition on highly disturbed habitats, like polar boulders, would be low level and ecologically unimportant (Connell 1985, Roughgarden 1986, Menge \& Sutherland 1987) seemed intuitively reasonable. Habitable space for

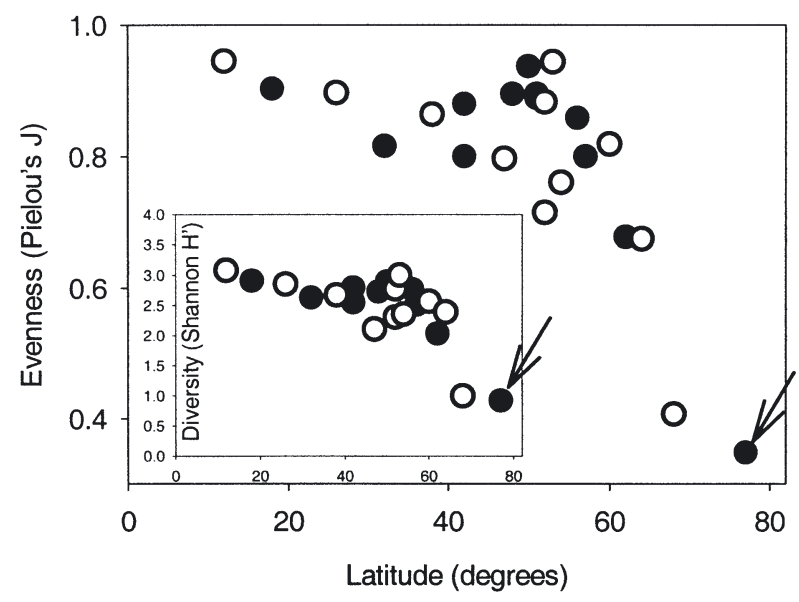

Fig. 4. Diversity of competition with latitude. Data are Pielou's $J$ (main) and Shannon-Wiener $H^{\prime}$ (insert) of competitor pairings in assemblages and are shown with symbols and arrow as in Fig. 3 

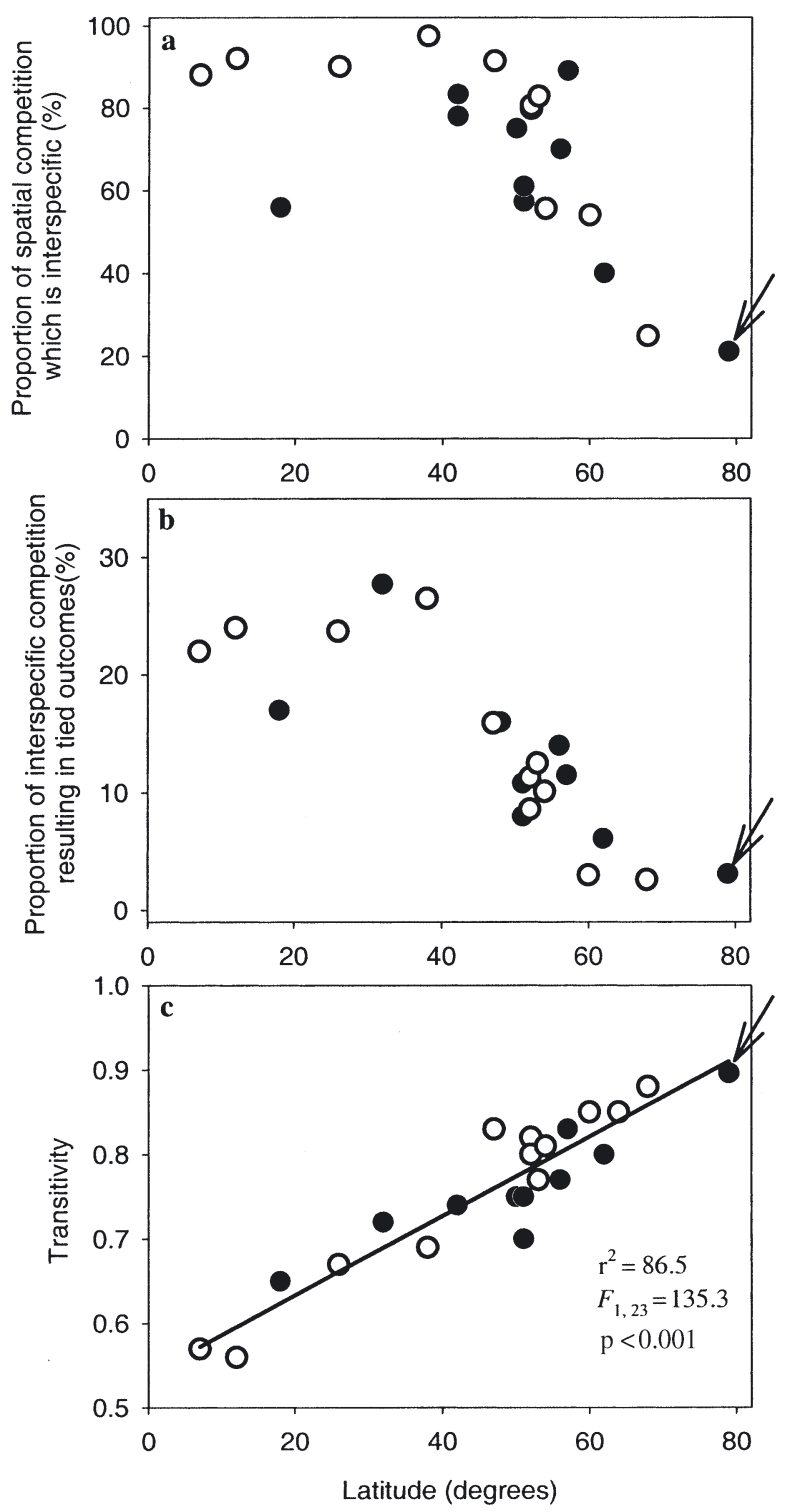

Fig. 5. Competition structure with latitude. Plots are (a) interspecific proportion of competition, (b) proportion of interspecific competition resulting in tied outcomes and (c) transitivity (measured by Tanaka \& Nandakumar's 1994 index). Fitted line in (c) is regression for which the degree of fit and significance (ANOVA) are indicated on the plot. Data are shown as in Fig. 3

most species, however, is restricted to the undersurface. Here, there are patches of biotic abundance where competition is severe. Even on small boulders with $<10 \%$ cover, spatial competition on the undersurface can be common (Figs. 1 \& 2). Competition may, therefore, be a major factor controlling assemblage structure in polar benthos (Barnes 2002, Barnes \& DeGrave 2002). Recent work synthesising studies of competition in marine benthos (Barnes 2002) suggested the structure of competition changed with latitude. This generated testable predictions on the nature of organism interactions beyond $68^{\circ}$. Our results, reported here, from $9^{\circ}$ latitude higher than previously reported studies, confirmed predicted assemblage structure at high latitude and demonstrated bipolar similarities in competition.

Despite the presence of many taxa, interference competition was dominated by encounters between colonial animals (mainly cheilostome bryozoans), as stated by Hypothesis 1. Schoener et al. (1978) demonstrated both spatial and temporal elements to the dynamic balance in the fight for space between colonial and unitary invertebrates. Bryozoans, particularly cheilostomes, are often important components of young communities on ephemeral substrata (Jackson \& Buss 1975, Schoener et al. 1978, Hughes \& Jackson 1992, Holmes et al. 1997, Maughan \& Barnes 2000a). They are, however, usually outcompeted by sponges, ascidians or corals in temperate and tropical seas (Quinn 1982, Russ 1982, Nandakumar 1995, Maughan \& Barnes 2000b). Ultimately in many tropical localities, major spatial competition comes to be dominated by showdowns between corals (Karlson 1999) except in the presence of intense disturbance when sponges may predominate (Wulff 1995). Usually only at very high latitude do assemblages, or their competition, seem to be shaped by just 1 to 2 species (Tables 1 \& 2; Dayton 1989, Barnes \& Clarke 1998). Domination of highly disturbed assemblages by relatively poor competitors (Fig. 6) can, however, have parallels elsewhere (Dayton 1971, Paine 1979). At low latitudes too, poorer competitors amongst the colonial cnidarians have been found to dominate assemblages with high levels of disturbance (Karlson 1983, 1999). At

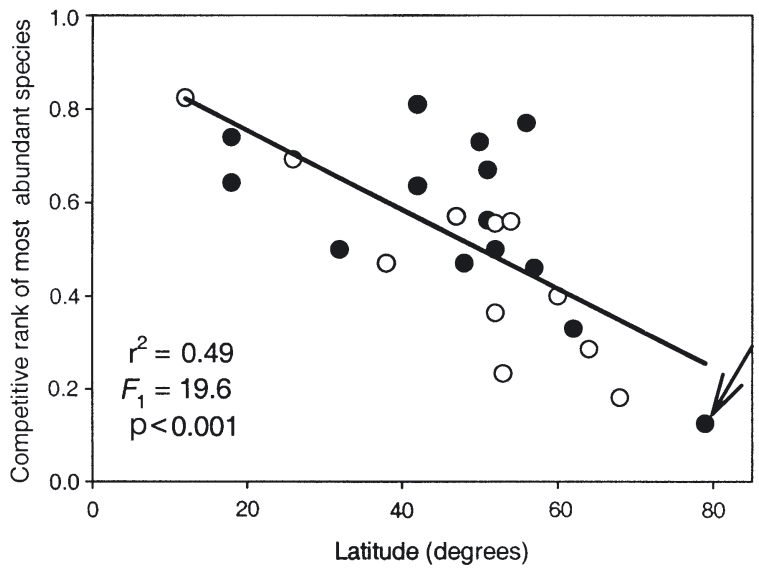

Fig. 6. Dominant species in competition with latitude. Competitive rank of the most abundant single species in assemblages with latitude. Fitted line is regression for which the degree of fit and significance (ANOVA) is indicated on the plot.

Data are shown with symbols and arrow as in Fig. 3 
our West Spitsbergen study site, $>98 \%$ of all fights for space and even $80 \%$ of between species competition involved the cheilostome bryozoan Harmeria scutulata. Synthesis of the literature on cheilostome competition shows that there are a number of clear and linear trends in structure with latitude (Figs. 3-6) with strong implications for assemblage diversity and responses to climate change.

\section{Variability in marine benthic community structure with latitude}

For many decades, ecologists have sought explanations for large-scale change in organisms from poles to tropics. Obvious terrestrial declines in biota polewards have only recently been matched with convincing marine data, and even then only for certain taxa and coastlines in the northern hemisphere (Kendall \& Aschan 1993, Roy et al. 1998, Clarke \& Lidgard 2000). No matching clines have been found in the southern hemisphere (Clarke 1992). The differential age, topography (land vs sea), depth and substratum of the 2 polar regions make meaningful comparisons difficult. In addition many taxa are highly speciose in the Southern Ocean (Foster 1974, Van Soest 1994, Hayward 1995, Glasby \& Alavrez 1999, Clarke \& Johnston 2003). It therefore seems unlikely that the 'strong' northern biota trends with latitude will be found in the south.

A number of suggested large-scale ecological patterns with latitude have come to be disregarded. This has been either through lack of supporting data or production of confounding data (McGuiness 1990, Pearse et al. 1991, Stanwell-Smith et al. 1999, but see Arntz \& Gili 2001). Nevertheless, certain aspects of biological community change with latitude are supported by data in both hemispheres. Wind speed and wave height increase near linearly from equator to subpolar latitudes (Bentamy et al. 1996). Ice scouring also increases towards both poles (Dayton 1990, Gutt et al. 1996, Conlan et al. 1998, Gutt 2001). Overall, this does suggest disturbance to shallow marine biological communities increases with latitude (Barnes 2002). This has important consequences for a feature of biological community structure, which also changes with latitude in both hemispheres: outcomes and transitivity in interference competition (Barnes 2002).

The outcome and prevalence of intraspecific competition may differ markedly from those of interspecific encounters. The implications of intraspecific competition can also be quite different (Karlson 1980, 1999) from those of interspecific interactions. Intraspecific encounters are common in specific niches like kelp blades (Stebbing 1973) or rocky shore zones (Connell 1961) where few species occur, or for mates between mobile animals (Wagnon et al. 1966, Clutton-Brock et al. 1979). The proportion of interspecific competition in the high arctic study assemblage was the lowest ( $20 \%$ of interactions) in any like group of competitors. Only the highest latitude $\left(68^{\circ} \mathrm{S}\right)$ southern polar data obtained to date (Barnes \& Clarke 1998) approached this level (Fig. 5a). Also, in common with other high latitude data, we found the highest proportions of tied outcomes in intraspecific and lowest in interspecific encounters (Fig. 5b). Hypothesis 3, that intraspecific interactions would mainly result in tied outcomes, was thus supported, as $>94 \%$ did. Hypothesis 4, that overgrowth would typically result from interspecific interactions, was also supported, as $>96 \%$ did. Unlike in some taxa (Karlson 1999), ties in bryozoan competition here were essentially similar whether intra- or interspecific. That is, nearly all involved battles which neither competitor won, and only in a very few $(<1 \%)$ intraspecific meetings did fusion take place. Tied outcomes are, however, very common in certain other taxa, such as sponges or ascidians (Grosberg 1981, Schmidt \& Warner 1986) irrespective of latitude.

The high proportion of interspecific contests resulting in overgrowth certainly contributed to the study assemblage being highly hierarchical. This supported Hypothesis 5 and resembled the strict pecking orders of vertebrate competition structure (Wagnon et al. 1966, Clutton-Brock et al. 1979). Compared with similar (bryozoan) assemblages elsewhere the organisation of competition was the most hierarchical reported. Nevertheless it fitted Barnes' (2002) latitudinal relationship. Over the last few decades it has been shown that competition in tropical marine assemblages is relatively intransitive, both within and between various invertebrate groups (Jackson \& Buss 1975, Buss \& Jackson 1979, Chornesky 1989, Barnes 2002). Recently it has become clear that this intransitivity (often termed a network) is due to a number of features: (1) reversals in competitive outcomes between competitor pairings, (2) loops whereby low ranked species beat superiors and (3) because of stable and common outcomes being ties (Tanaka \& Nandakumar 1994). Comparison of the literature reveals clear trends in competition as well as in assemblage transitivity. The proportion of total competitors meeting each other decreases with latitude (Fig. 3a,b) whilst that just involving the most abundant species increases (Fig. 6a). The diversity of competition is thus depressed at high latitude and raised at low latitude (Fig. 4). Clearly it has been important to standardise competitor matrices to a fixed number ( 6 or 7 ) of species for these comparisons, otherwise this could simply be caused by decreasing species richness (Clarke \& Lidgard 2000). Trends in whole assemblage 
diversity may be difficult to establish for any taxa towards both poles. As latitudinal change in diversity of bryozoan competition seems robust though, a logical step is to probe its generality. Extrapolating small scale competitive encounters to other scales will not be easy. At least one approach could be to take multiple small-scale samples at progressively scaled distances. Furthermore, investigation in other taxa is also problematical, not only due to differential abundance and species richness in space, but also in measuring the outcomes of competition. Competitive encounters between many animals are hard to record; for example many taxa are mobile and contests could not be known unless witnessed. Differences in competition structure between tropical and polar latitudes (which are typically at extremes of a continuum in many features, such as transitivity) have implications for the way in which diversity is generated and maintained. They are likely to strongly influence the response of assemblages and communities to climate change.

\section{Implications of high latitude hierarchies}

In a system where 1 competitor is beaten by all others and yet monopolises space, some factor must be restricting assemblage development. At polar latitudes this is almost certainly disturbance by ice. In the shallows, good competitors do not have time to completely overgrow the highly abundant, fast growing competitive inferior species before assemblages become scraped clean and the colonisation process restarts. Communities experience frequent and powerful disturbance, principally by ice scour, but also wave action, megafauna foraging, melt water runoff, anoxia and pollution (Dayton 1990, Gutt et al. 1996, McCook \& Chapman 1997, Gutt 2001). Despite this both the Arctic and Antarctic may have rich nearshore benthos (Gallardo \& Castillo 1969, Zamorano 1983, Rauschert 1991, Brey \& Clarke 1993, Arntz et al. 1994). Knowledge of community richness or structure from the high polar latitudes is restricted to few sites in both Antarctica (Uschakov 1963, Dayton et al. 1974, Kirkwood \& Burton 1988, Dayton 1989) and in the Arctic (Kendall \& Aschan 1993, Holte et al. 1996, Conlan et al. 1998, Dahle et al. 1998, Sejr et al. 2000).

Anchor ice is a major factor driving high polar zonation (Dayton et al. 1974), whereas ice scour seems more important at midpolar latitudes (Arntz et al. 1994, Gutt 2001). Both of these may, however, be effective at generating zonation and maintaining diversity of some taxa because of the structure of competition. But this structure requires mechanical disturbance to prevent competitively superior species simply monopolising all space. Sea temperature rises predicted by the Hadley centre model 3 (Murphy \& Mitchell 1995) could dramatically change the disturbance regime through moderating floating ice levels. Already major temperature increases and ice decreases have been found in high latitude lakes (Quale et al. 2002). Marked alterations in terrestrial polar ecological systems have already been noted (Convey et al. 2002, Walther et al. 2002). Our principal areas of concern have, to date, been thermal tolerances of organisms. This may be particularly important in the Antarctic where much of the benthos is stenothermal (Peck et al. 1997, Peck 2002) and currently experiences just $3^{\circ} \mathrm{C}$ annual variability (Arntz et al. 1994). In the high arctic waters around Spitsbergen up to $7^{\circ} \mathrm{C}$ seasonal variation may, however, be experienced (Loeng 1991, Quadfasel et al. 1991). Initial influences of warming are likely to increase floating ice due to iceshelf collapses (Doake \& Vaughan 1991) but then decrease because of reduced winter sea surface freezing. We predict that changes in ice loading of polar waters will have a profound effect on community structure. In the short term, reduced disturbance should increase diversity in encrusting Arctic (and Antarctic) species and reduce the abundance of the currently pervasive poorest competitors. In effect the polar nearshore environment may act as a giant, semi-natural, intermediate disturbance experiment (see Connell 1978, Huston 1979). Eventually the most competitively superior species could take over large tracts of sea-bed. In addition some high latitude species would disappear, to be replaced by midlatitude species. Monitoring of small scale competitive outcomes in shallow benthos may provide an easy, early and graduated way to monitor marine community change. Before this, the generality of our findings in the high polar environment need to be established as well as variability with scale.

\section{CONCLUSIONS}

In harsh environments competition can become less important-at least at the community level. To the individual, in contrast, the implications are more important, because the outcomes of interspecific meetings nearly always result in a clear loser who is overgrown. Due to frequent disturbance, these communities are not in a state of equilibrium, but one of constant succession (intermediate disturbance hypothesis). Species diversity and composition in such assemblages are particularly vulnerable to climate change (global warming) as disturbance may be less frequent and intense. 
Acknowledgements. The authors wish to thank all the scientific staff and crew of the Polish Academy of Sciences RV 'Oceania'. We are also very grateful to Jan Marcin Węsławski for the invitation to D.K.A.B. to join the 2002 West Spitsbergen 'Oceania' cruise. This study was financially supported by Grant 6 PO4E 04421 from the Polish State Committee for Scientific Research. Finally we thank Prof. Lloyd Peck for comments leading to a much improved manuscript.

\section{LITERATURE CITED}

Arntz WE, Gili JM (2001) A case for tolerance in marine ecology: let us not put out the baby with the bathwater. Sci Mar 65(Suppl 2):283-299

Arntz WE, Brey T, Gallardo VA (1994) Antarctic zoobenthos. Oceanogr Mar Biol Annu Rev 32:251-303

Barnes DKA (2000) Diversity, recruitment and competition on island shores at polar locations compared with lower latitudes; encrusting community examples. Hydrobiologia 440:37-44

Barnes DKA (2002) Polarization of competition increases with latitude. Proc R Soc Lond B 269:2061-2069

Barnes DKA, Clarke A (1998) The ecology of an assemblage dominant: the encrusting bryozoan Fenestrulina rugula. Invertebr Biol 117:331-340

Barnes DKA, DeGrave S (2002) Modelling multivariate determinants of growth in Antarctic bryozoans. Proc Int Bryozoology Conf, Balkema, p 7-17

Bentamy A, Grima N, Quilfen Y, Harscoat V, Maroni C, Pouliquen S (1996) An atlas of surface wind from ERS-1 Scatterometer measurements. IFREMER, Plouzane

Brey T, Clarke A (1993) Population dynamics of marine benthic invertebrates in Antarctic and Subantarctic environments: are there unique adaptations? Antarct Sci 5: 253-266

Buss LW, Jackson JBC (1979) Competitive networks: nontransitive competitive relationships in cryptic coral reef environments. Am Nat 113:223-234

Chornesky EA (1989) Repeated reversals during spatial competition between corals. Ecology 70:843-855

Clarke A (1992) Is there a latitudinal diversity cline in the sea? Trends Ecol Evol 7:286-287

Clarke A, Johnston N (2003) Antarctic benthic diversity. Oceanogr Mar Biol Annu Rev 41:47-114

Clarke A, Lidgard S (2000) Spatial patterns of diversity in the sea: bryozoan species richness in the North Atlantic. J Anim Ecol 69:799-814

Clutton-Brock TH, Albon SD, Gibson RM, Guiness FE (1979) The logical stag: adaptive aspects of fighting in red deer (Cervus elaphus L.). Anim Behav 27:211-225

Conlan KE, Lenihan HS, Kvitek RG, Oliver JS (1998) Ice scour disturbance to benthic communities in the Canadian high Arctic. Mar Ecol Prog Ser 166:1-16

Connell JH (1961) The influence of interspecific competition and other factors on the distribution of the barnacles Chthamalus stellatus. Ecology 42:710-723

Connell JH (1978) Diversity in tropical rain forests and coral reefs. Science 199:1302-1310

Connell JH (1985) Variation and persistence of rocky shore populations. In: Moore PG, Seed R (eds) The ecology of rocky coasts. Hodder \& Stoughton, London, p 57-69

Convey P, Pugh PJA, Jackson C, Murray AWA, Ruhland CT, Xiong FS, Day TA (2002) Response of Antarctic terrestrial arthropods to multifactorial climate manipulation over a four year period. Ecology 83:3130-3140

Craig S (1994) Intraspecific fusion in the encrusting bryozoan
Fenestrulina sp. In: Hayward PJ, Ryland JS, Taylor PD (eds) Biology and palaeobiology of bryozoans. Olsen \& Olsen, Fredensborg, p 51-55

Dahle S, Denisenko SG, Denisenko NV, Cochrane S (1998) Benthic fauna in the Penchora Sea. Sarsia 83:183-210

Darwin C (1859) On the origin of species. Murray, London

Dayton PK (1971) Competition, disturbance and community organisation: the provision and subsequent utilisation of space in a rocky intertidal community. Ecol Monogr 41: 351-389

Dayton PK (1989) Interdecadal variation in an Antarctic sponge and its predators from oceanographic climate shifts. Science 245:1484-1486

Dayton PK (1990) Polar benthos. In: Smith WO (ed) Polar Oceanography. Academic Press, London, p 631-685

Dayton PK, Robilliard GA, Paine RT, Dayton, LB (1974) Biological accommodation in the benthic community at McMurdo Sound, Antarctica. Ecol Monogr 44:105-128

Denisenko SG, Denisenko NV (1995) The south-eastern part of the Barents Sea: Possibility of investigations for longterm changes of the bottom fauna under climatic fluctuations. In: Matishov G, Galaktionov $K$, Chinarina A, Denisenko SG, Denisenko NV, Zenzerov V (eds) Modern state and perspective of ecosystem studies of the Barents, Kara and Laptev Seas. Akademika Nauk, Murmansk, p 28-29

Diamond JM (1987) Competition among different taxa. Nature 326:241

Doake CSM, Vaughan DG (1991) Rapid disintegration of the Wordie ice shelf in response to atmospheric warming. Nature 350:328-330

Farman JC, Gardiner BG, Shanklin JD (1985) Large losses of total ozone in Antarctica reveal seasonal ClO_x/NOx interaction. Nature 315:207-210

Foster MW (1974) Recent Antarctic and Subantarctic brachiopods. Antarct Res Ser 21:1-189

Gallardo VA, Castillo J (1969) Quantitative benthic survey of the infauna of Chile Bay (Greenwich I, South Shetland Is.). Gayana 16:3-18

Glasby CJ, Alavrez B (1999) Distribution patterns and biogeographic analysis of Austral Polycheata (Annelida). J Biogeogr 26:507-533

Grosberg RK (1981) Competitive ability influences habitat choice in marine invertebrates. Nature 290:700-702

Gutt J (2001) On the direct impact of ice on marine benthic communities, a review. Polar Biol 24:553-564

Gutt J, Starmans A, Dieckmann G (1996) Impact of iceberg scouring on polar benthic habitats. Mar Ecol Prog Ser 137: $311-316$

Hayward PJ (1995) Antarctic cheilostomatous Bryozoa. Oxford University Press, Oxford

Hochberg ME, Lawton JH (1990) Competition between kingdoms. Trends Ecol Evol 5:367-370

Holmes NJ, Harriott VJ, Banks SA (1997) Latitudinal variation in patterns of colonisation of cryptic calcareous marine organisms. Mar Ecol Prog Ser 155:103-113

Holte B, Dahle S, Gulliksen B, Naes K (1996) Some macrofaunal effects of local pollution and glacier induced sedimentation, with indicative chemical analyses, in the sediments of two arctic fjords. Polar Biol 16:549-557

Hughes DJ, Jackson JBC (1992) Distribution and abundance of cheilostome bryozoans on the Carribean reefs of central Panama. Bull Mar Sci 51:443-465

Huston M (1979) A general hypothesis of species diversity. Am Nat 113:81-101

Jackson JBC (1979) Morphological strategies of sessile animals. In: Larwood G, Rosen GR (eds) Biology and system- 
atics of colonial organisms. Academic Press, London, p 499-555

Jackson JBC, Buss L (1975) Allelopathy and spatial competition among coral reef invertebrates. Proc Natl Acad Sci 72: 5160-5163

Karlson RH (1980) Alternative competitive strategies in a periodically disturbed habitat. Bull Mar Sci 30:894-900

Karlson RH (1983) Disturbance and monopolisation of a spatial resource by Zooanthus sociatus. Bull Mar Sci 33: 118-131

Karlson RH (1999) Dynamics of coral communities. Kluwer Academic, London

Kendall MA, Aschan M (1993) Latitudinal gradients in the structure of macrobenthic communities: a comparison of arctic, temperate and tropical sites. J Exp Mar Biol Ecol 172:157-169

Kirkwood JM, Burton HR (1988) Macrobenthic species assemblages in Ellis Fjord, Vestfold Hills, Antarctica. Mar Biol 97:445-457

Knight-Jones EW, Moyse J (1961) Intraspecific competition in sedentary marine animals. Symp Soc Exp Biol 15:72-95

Loeng H (1991) Features of the physical oceanographic conditions of the Barents Sea. In: Sakshaug E, Hopkins CCE, Oritsland NA (eds) Proceedings of the Pro Mare Symposium on Polar Marine Ecology, Trondheim, 12-16 May 1990. Polar Res 10:5-18

Maughan B, Barnes DKA (2000a) Epilithic boulder communities of Lough Hyne, Ireland: the influences of water movement and sediment. J Mar Biol Assoc 80:767-776

Maughan B, Barnes DKA (2000b) A 'minimum stress inflexion' in relation to environmental and biological influences on the dynamics of subtidal encrusting communities. Hydrobiologia 440:101-109

McCook LJ, Chapman ARO (1997) Patterns and variations in natural succession following massive ice-scour of a rocky intertidal seashore. J Exp Mar Biol Ecol 214:121-147

McGuiness K (1990) Physical variability, diversity gradients and the ecology of temperate and tropical reefs. Aust J Ecol 15:465-476

McKinney FK (1995) One hundred million years of competitive interactions between bryozoan clades: asymmetrical but not escalating. Biol J Linn Soc 56: 465-481

Menge BA, Sutherland JP (1987) Community regulation: variation in disturbance, competition and predation in relation to environmental stress and recruitment. Am Nat 130: $730-757$

Murphy JM, Mitchell JFB (1995) Transient response of the Hadley Centre coupled ocean-atmosphere model to increasing carbon dioxide. J Climate 8:36-514

Nandakumar K (1995) Competitive interactions among sessile organisms in Tomioka Bay, South Japan: importance of light conditions on the panel surface. Mar Biol 121: 713-719

Paine RT (1974) Intertidal community structure: experimental studies on the relationship between a dominant competitor and its principal predator. Oecologia 15:710-719

Paine RT (1979) Disaster, catastrophe, and local persistence of the sea palm Postelsia palmaeformis. Science 205:685-687

Pearse JS, McClintock JB, Bosch I (1991) Reproduction in Antarctic benthic marine invertebrates: tempos, modes and timing. Am Zool 31:65-80

Peck LS (2002) Ecophysiology of Antarctic marine ectotherms: limits to life. Keynote contribution, Antarctic Treaty Organisation Scientific Committee on Antarctic Research. Polar Biol 25:31-40

Peck LS, Rhodes MC, Curry GB, Ansell A (1997) Physiology. In: Kaesler RL (ed) Treatise on invertebrate palaeontology,
$\mathrm{H}$ Brachiopoda. University of Kansas, Lawrence, KA, p 213-240

Quadfasel D, Sy A, Wells D, Tunik A (1991) Warming in the Arctic. Nature 350:385

Quayle W, Peck LS, Peat HJ, Ellis-Evans JC, Harrigan PR (2002) Extreme responses to climate change in Antarctic Lakes. Science 295:645

Quinn JF (1982) Competitive hierarchies in marine benthic communities. Oecologia 54:129-135

Rauschert M (1991) Ergebnisse der faunistischen Arbeiten im Benthal von King George Island (Südshetlandinseln, Antarktis). Ber Polarforsch 76:1-75

Roughgarden J (1986) A comparison of food-limited and space-limited animal competition communities. In: Diamond J, Case TJ (eds) Community ecology. Harper \& Row, New York, p 492-516

Roy K, Jablonski D, Valentine JW, Rosenberg G (1998) Marine latitudinal diversity gradients: tests of causal hypotheses. Proc Natl Acad Sci USA 95:3699-3702

Russ GR (1982) Overgrowth in a marine epifaunal community: competitive hierarchies and competitive networks. Oecologia 53:12-19

Schmidt GH, Warner GF (1986) Spatial competition between colonial ascidians: the importance of stand-off. Mar Ecol Prog Ser 31:101-104

Schoener A, Long ER, DePalma JR (1978) Geographic variation in artificial island curves. Ecology 59:367-382

Schoener TW (1983) Field experiments on interspecific competition. Am Nat 122:240-285

Sebens KP (1986) Spatial relationships among encrusting marine organisms in the New England subtidal zone. Ecol Monogr 56:73-96

Sejr MK, Jensen KT, Rysgaard S (2000) Macrobenthic community structure in a high-arctic East Greenland fjord. Polar Biol 23:792-801

Stanwell-Smith D, Peck LS, Clarke A, Murray AWA, Todd CD (1999) The distribution, abundance and seasonality of pelagic marine invertebrate larvae in the maritime Antarctic. Phil Trans R Soc Lond B 354:471-484

Stebbing ARD (1973) Competition for space between the epiphytes of Fucus serratus L. J Mar Biol Assoc UK 53: $247-261$

Swerpel S (1985) The Horsund Fiord: water masses. Pol Polar Res 6(4):475-496

Tanaka M, Nandakumar K (1994) Measurement of the degree of intransitivity in a community of sessile organisms. J Exp Mar Biol Ecol 182:85-95

Tanner JE (1997) Interspecific competition reduces fitness in scleractinian corals. J Exp Mar Biol Ecol 214:19-34

Todd CD, Turner SJ (1988) Ecology of sublittoral cryptic epifaunal assemblages. II. Non-lethal overgrowth of encrusting bryozoans by colonial ascidians. J Exp Mar Biol Ecol 74:113-126

Turner SJ, Todd CD (1994) Competition in encrusting bryozoan assemblages: the influence of encounter angle, site and year on outcome variability. J Mar Biol Assoc UK 74: 603-622

Ushakov PV (1963) Some characteristics of the distribution of the bottom fauna off the coast of East Antarctica. Inf Byull Sov Antarkt Eksped 40:5-13

Van Soest RWM (1994) Demosponge distribution patterns. In: Van Soest RWM, Van Kempen TMG, Braekman JC (eds) Sponges in time and space. Balkema, Rotterdam, p 213-223

Wagnon KA, Loy RG, Rollins WC, Carrol FD (1966) Social dominance in a herd of Angus, Hereford and shorthorn cows. Anim Behav 14:474-479 
Walther GR, Post E, Convey P, Menzel A and 5 others (2002) Ecological responses to recent climate change. Nature 416:389-395

Wẹsławski JM, Zajączkowski M, Kwaśniewski S, Jezierski J, Moskal W (1988) Seasonality in an Arctic fjord ecosystem: Horsund, Spitsbergen. Polar Res 6:185-189

Wẹsławski JM, Wiktor J, Zajączkowski M, Swerpel S (1993)

Editorial responsibility: Otto Kinne (Editor),

Oldendorf/Luhe, Germany
Intertidal zone of Svalbard 1. Macroorganism distribution and biomass. Polar Biol 13:73-79

Wulff JL (1995) Effects of a hurricane on survival and orientation of large erect coral reef sponges. Coral Reefs 14:55-61

Zamorano JH (1983) Zonacion y biomasa de la macrofauna betonica en Bahia South, Archipelago de palmer, Antarctica. Inst Antarctico Chil Ser Cient 30:27-38

Submitted: November 21, 2002; Accepted: June 14, 2003

Proofs received from author(s): September 1, 2003 